\title{
Gastric Lesions in Culled Sows: An Underestimated Welfare Issue in Modern Swine Production
}

\author{
Piotr Cybulski ${ }^{1} \mathbb{D}$, Aleksandra Woźniak ${ }^{2, * \mathbb{D}}$, Joachim Urban ${ }^{3}$ and Tomasz Stadejek ${ }^{2}$ \\ 1 Goodvalley Agro S.A., Dworcowa 25, 77-320 Przechlewo, Poland; piotr.cybulski@goodvalley.com \\ 2 Department of Pathology and Veterinary Diagnostics, Institute of Veterinary Medicine, Warsaw University of \\ Life Sciences-SGGW, Nowoursynowska 159C, 02-776 Warsaw, Poland; tomasz_stadejek@sggw.edu.pl \\ 3 Independent Researcher, Mickiewicza 7, 77-420 Lipka, Poland; urbanj@vp.pl \\ * Correspondence: aleksandra_wozniak@sggw.edu.pl
}

Citation: Cybulski, P.; Woźniak, A.; Urban, J.; Stadejek, T. Gastric Lesions in Culled Sows: An Underestimated Welfare Issue in Modern Swine Production. Agriculture 2021, 11, 927. https://doi.org/10.3390/ agriculture11100927

Academic Editor:

Grzegorz Woźniakowski

Received: 20 August 2021

Accepted: 22 September 2021

Published: 27 September 2021

Publisher's Note: MDPI stays neutral with regard to jurisdictional claims in published maps and institutional affiliations.

Copyright: (c) 2021 by the authors. Licensee MDPI, Basel, Switzerland. This article is an open access article distributed under the terms and conditions of the Creative Commons Attribution (CC BY) license (https:/ / creativecommons.org/licenses/by/ $4.0 /)$.

\begin{abstract}
Specific anatomy of the porcine stomach results in a high risk of ulceration in the pars oesophagea. A fully developed ulcer leads to intermittent gastrointestinal bleeding followed by clinical symptoms of chronic pain; thus, gastric ulceration in pigs causes significant production losses and serious welfare problems. Nowadays, gastric ulceration is common in domestic pigs throughout the world, but a great deal of attention has been directed at finishers. This paper was intended to provide new data on the prevalence of the disease in commercially reared highly prolific sows. The study was carried out on 329 culled sows from four commercial farms located in Northern Poland. The severity of gross pathological lesions of pars oesophagea was assigned to grade 0 (no lesions), 1 (parakeratosis), 2 (erosion), or 3 (gastric ulceration with or without stenosis) by a veterinary practitioner. Abattoir analysis revealed $66.6 \%$ of sows' stomachs with some degree of alterations. Gastric ulceration was detected in $45.5 \%$ of examined organs. Parakeratosis and erosion were found in 1.2 and $15.8 \%$ of stomachs, respectively. The investigation did not find any oesphageal strictures. Our investigation of the problem in high health status hyper-prolific sows showed the lowest prevalence of gastric lesions (i.e., ulcerative and preulcerative alterations collectively) compared to earlier studies but the highest percentage of gastric ulcers. The results indicate that gastric ulcers may be a highly prevalent and underestimated welfare issue in sows in modern pig production, worth further studies focusing on particular risk factors related to feeding, genetics, management issues, and sows longevity.
\end{abstract}

Keywords: pigs; sows; gastric ulcers; abattoir survey

\section{Introduction}

In contrast to other monogastric animal species (except the squamous region of the horse's stomach), gastric lesions in pigs almost exclusively occur in the pars oesophagea, a relatively small region located around the oesophageal opening and lined by stratified squamous epithelium, which does not contain glands. Such a specific microanatomy of the area is a reason for a complete lack of innate capability of buffering the negative impact of irritating stomach content or other noxious stimuli. Gross pathological lesions of the pars oesophagea in pigs range from parakeratosis to erosion, and eventually deep ulceration [1]. The disease is known in all major pig producing countries [2,3] and causes undisputable welfare problems; a fully developed gastric ulcer leads to intermittent gastrointestinal bleeding followed by clinical signs of chronic anaemia and pain, or acute haemorrhage causing sudden death and may lead to significant economic losses in a herd [4-6]. Occasionally, gastric ulcer heals per secundam intentionem, which results in a stricture of oesophageal opening, which may lead to chronic wasting [4].

For obvious reasons, the vast majority of peer-reviewed reports on the prevalence of gastric lesions in pigs deal with the data obtained from finishers at slaughter [7-10]. Much less is known about the frequency of the disease among sows. Its occurrence was analysed 
only in the last few years, and the data were published in the form of professional reports, in local languages, and are not widely accessible [11-16]. Figures regarding the prevalence of gastric lesions in sows in Poland have still not been brought out.

As previous research in finishers has indicated, gastric ulcers cause behavioral changes, indicating pain [6] and almost certainly the same impact that gastric ulcers may have in sows, seriously affecting their welfare. Moreover, the link between reduced reproductive performance and stress caused by gastric-ulcer-related chronic pain cannot be excluded.

The goal of this study was to investigate the prevalence of gastric lesions in culled sows from modern high-performing farms located in Poland.

\section{Materials and Methods}

The study was performed on a group of 329 DanBred sows culled in March 2020. The major culling reasons were reproductive disorders and lameness. All animals were reared under conditions meeting the requirements of Council Directive 2008/120/EC of 18 December 2008, laying down the minimum standards for the protection of pigs, in 4 high performing commercial herds located in Northern Poland, belonging to a single production company, with $3300,3600,5000,8000$ sows in each farm. The number of the analysed animals per farm was $35,21,114,159$, respectively.

Despite being reared in different locations, all sows were managed using the same production procedures-in each farm, animals were housed in a traditional weakly farrowing system on a slatted floor and received wheat and barley-based feed, from the same feed mill, where the components were disintegrated using a hammer mill, dry steam conditioned at $80^{\circ} \mathrm{C}$, and pelleted to $4 \times 25 \mathrm{~mm}$ cylindrical pellets. During group housing, the sows were fed using floor feeding systems. The level of protein, fat and fiber in feed for lactating sows was $16.1 \%, 5.5 \%, 4.8 \%$, respectively. In gestation feed, these values equalled $13.4 \%, 4.1 \%, 5.1 \%$, respectively. The lactation feed was offered from the 2 nd week before the expected farrow date until the 7th day after artificial insemination. Moreover, all herds had the same health status (Mycoplasma hyopneumoniae-positive, porcine reproductive and respiratory syndrome-negative, Actinobacillus pleuropneumoniae-negative, Brachyspira hyodysenteriae-negative, progressive atrophic rhinitis-negative) and prophylaxis program, which involved commercial vaccines against neonatal colibacillosis and Clostridium infections, influenza, erysipelas, porcine circovirus type 2, parvovirus and leptospirosis. The highly similar health status of sows from these 4 farms is further confirmed by a similar annual number of weaned piglets per sow (from 30.87 to 34.14) and the same annual culling rate (on average $52.6 \%$ ). The average age of slaughter sow in these herds was 128 weeks (4th parity sow). The share of culled nulliparous, primiparous, 2nd, 3rd, 4th, 5th, 6th, 7th and 8 th parity sows in the herds was $5.3 \%, 14.4 \%, 10.8 \%, 12.1 \%, 10.7 \%, 11.4 \%, 13.9 \%, 21.3 \%$, and $0.2 \%$, respectively. The most frequent reason for culling was reproductive failure and low reproductive performance $(42.4 \%)$, old age $(29.3 \%)$, locomotion disorders $(15.2 \%)$, and other reasons, including milking problems and poor body condition $(13 \%)$.

The sows were transported to the slaughterhouse on a truck meeting the requirements of Council Reregulation No 1/2005 of 22 December 2004 on the protection of animals during transport and related operations and amending Directives 64/432/EEC and 93/119/EC and Regulation No 1255/97 in 6 batches, from 49 to 66 animals in each. The feed was withdrawn for $12 \mathrm{~h}$ prior to the transportation. Depending on the farm location, transportation time varied from 2 to $4.5 \mathrm{~h}$. At the abattoir, the sows were electrically stunned, suspended vertically and bled out through the neck tissue the same day. Stomachs of the sows were opened along the greater curvature at approximately $20 \mathrm{~min}$ after slaughter, then they were emptied gently and washed under cold running water. Macroscopic pathological lesions in the pars oesophagea of each organ were categorized according to Kopinski and McKenzie as follows: normal epithelium (grade 0), parakeratosis (grade 1), erosion (grade 2), or developed ulcer with or without stenosis (grade 3) [17]. The evaluation was made by the same trained veterinary practitioner. For the purpose of the study, the available scores from the earlier reports [11-16], which used different systems for the classification of the 
alterations in the pars oesophagea, were adapted to the four-point scale. All forms of hyperkeratosis, regardless of the thickness (grade 1, or 1 to 3 in Danish studies; grade 1 and 2 in Dutch), were classified as grade 1 . Secondary lesions, i.e., erosions and ulcers, in spite of varying depth and diameter (grade 2, or from 4 to 5 for erosions, and from 3 to 4 , or 6 to 10 for ulcers in Danish studies; 3 and 4 for erosions, and 5 for ulcers in Dutch work), were adopted to grade 2 and 3, respectively (Supplementary Table S1).

\section{Results}

From a total number of 329 organs examined, 66.6\% (219/329) had gastric alterations. Pre-ulcerative lesions were noticed in $17.0 \%(56 / 329)$ of the animals: parakeratosis and erosion were found in $1.2 \%(4 / 329)$ and $15.8 \%$ (52/329), respectively. Gastric ulcers were the most prevalent lesion and were observed in $49.5 \%$ (163/329) of the stomachs, which makes $74.4 \%(163 / 219)$ of all organs with visible alterations.

\section{Discussion}

A gastric lesion is a well-recognized problem in pig production, but the data regarding sows are very limited $[11,12,16]$. In the present study, gastric lesions were analysed in a group of culled DanBred sows originating from four high health status farms in Poland. To enable comparisons to the results of the previous studies, all the data were normalised to the Kopinski and Mc Kenzie system used in the present study [17]. The comparison of such normalised scores showed that the percentage of intact stomachs observed in our investigation (33.4\%) was similar to that observed in a Danish study from $2004(31.9 \%)$ [16], while in the remaining surveys, it ranged from as little as $10 \%$ or $10.3 \%$ in the Netherlands in 2010 and 2017, respectively [11], to 29.5\% in a Polish report from 2018 [13] (Table 1). The incidence of parakeratosis in the current study was the lowest of all studies performed to date and present in just $1.2 \%$ of stomachs examined. Previous research showed erosions in 9.9 to $39.6 \%$ of stomachs, so our finding of $15.8 \%$ prevalence can be considered typical. Surprisingly, this and the previous report from Poland showed the highest prevalence of ulcers (in $49.5 \%$ and $51.6 \%$ stomachs, respectively), of all investigations performed to date. Only one Danish survey of 482 stomachs performed in 2014 approached a similar level, reaching $48.8 \%$ [15]. In contrast to the previous studies, our investigation did not find any strictures. Unfortunately, the analysis of available literature data does not allow to draw reasonable conclusions about types and overall duration of triggering factors required to develop such scarification.

Table 1. The occurrence of macroscopical lesions of the pars oesophagea in sows sampled in this study and in the previous reports from Denmark and the Netherlands.

\begin{tabular}{|c|c|c|c|c|c|c|c|}
\hline \multirow{2}{*}{$\begin{array}{l}\text { Country, Year } \\
\text { of Analyse }\end{array}$} & \multirow{2}{*}{$\begin{array}{l}\text { No. of } \\
\text { Sows }\end{array}$} & Normal & Parakeratosis & Erosion & Ulcer & Stricture & \multirow{2}{*}{ Ref. } \\
\hline & & \multicolumn{5}{|c|}{ Number/Percentage } & \\
\hline Netherlands, $1990^{a}$ & 224 & $28 / 12.5 \%$ & $140 / 62.5 \%$ & $44 / 19.6 \%$ & \multicolumn{2}{|c|}{$12 / 5.4 \%$} & [11] \\
\hline Denmark, $2004^{\text {a }}$ & 775 & $194 / 25.0 \%$ & \multicolumn{2}{|c|}{$364 / 47.0 \%$} & \multicolumn{2}{|c|}{$217 / 28.0 \%$} & [12] \\
\hline Denmark, 2004 & 263 & $84 / 31.9 \%$ & $114 / 43.3 \%$ & $26 / 9.9 \%$ & $37 / 14.1 \%$ & $2 / 0.8 \%$ & [16] \\
\hline Netherlands, $2010^{a}$ & 220 & $22 / 10.0 \%$ & $101 / 45.9 \%$ & $87 / 39.6 \%$ & \multicolumn{2}{|c|}{$10 / 4.5 \%$} & [11] \\
\hline Denmark, 2013 & 1023 & $185 / 18.1 \%$ & $223 / 21.8 \%$ & $96 / 9.4 \%$ & $447 / 43.7 \%$ & $72 / 7.0 \%$ & [14] \\
\hline Netherlands, $2017^{\text {a }}$ & 184 & $19 / 10.3 \%$ & $106 / 57.7 \%$ & $58 / 31.6 \%$ & \multicolumn{2}{|c|}{$1 / 0.6 \%$} & [11] \\
\hline Poland, 2018 & 95 & $28 / 29.5 \%$ & $6 / 6.3 \%$ & $12 / 12.6 \%$ & $49 / 51.6 \%$ & $0 / 0 \%$ & [13] \\
\hline Poland, 2020 & 329 & $110 / 33.4 \%$ & $4 / 1.2 \%$ & $52 / 15.8 \%$ & $163 / 49.5 \%$ & $0 / 0 \%$ & This study \\
\hline
\end{tabular}

a_full data regarding classification to different classes were not available.

It can only be speculated that similarly to fatteners, where growing prevalence of gastric ulcers has been linked to the intensification of production in the last decades [18], such a relationship exists also in sows. However, these changes were not evenly implemented across Europe. The publication by Research Institute for Pig Husbandry indicated that, in 1995, the country average number of piglets weaned per sow per year (PWSY) in 
the Netherlands and Denmark was similar, 21.59 and 21.80, respectively [19]. However, according to the data presented in the 2015 Pig Cost of Production in Selected Countries Report an average Dutch farm achieved 29.52, whereas Danish 31.26 PWSY [20]. The report from 2019 shows the gap in sows' prolificacy to further expand, i.e., 30.10 and 33.60 PWSY in the Netherlands and Denmark, respectively [21]. The question of whether the more dynamic increase in sows' prolificacy may impact the prevalence of gastric lesions is difficult to answer. Nevertheless, in the Netherlands, where the increase in prolificacy was less dynamic than in Denmark, the data collected over the last three decades did not show any major shifts in the prevalence of different gastric lesions. On the other hand, in Denmark, a remarkable decrease in the prevalence of preulcerative alterations and increase in the occurrence of ulcers and strictures were observed between 2004 and 2014 (Table 1) $[12,14,16]$. The data from Poland is limited to this and one study from 2018 on highly prolific sows from the same company where the PWSY reached 34.65 , similarly to Denmark $[13,21]$.

Other sow management practices could also be attributed to the high incidence of ulcers in recent years in Denmark and Poland. Regardless of the fact that all the animals examined in our study were fed pelleted feed, what is generally associated with the higher occurrence of gastric alterations [7,22-24], other predisposing determinants might not remain underestimated. Among possible triggering factors, the presence of locomotory disorders in sows has already been proven to be significantly associated with the higher occurrence of gastric ulcer and scarification [12]. Another study indicated the lack of statistically significant differences in gastric health (measured as the proportion of animals with ulcers and scars, in sows slaughtered due to cessation of production and in those culled due to other, typical reasons); however, odds ratios indicated a tendency for the incidence of gastric ulcers to be greater in sows culled due to other reasons [25]. Even though $15.2 \%$ of slaughter sows originating from the herds evaluated in the current study had developed some degree of locomotory problems (which is rather typical of modern production with a range from 9 to $27 \%$ ) [26-29] such correlation could not have been determined due to a lack of assignment of the organs to the particular animals. According to the previous publications, the prevalence of the disease was simultaneously increasing with sows' age [12]; significantly better gastric health was observed in sows up to the 3rd parity [25]. Despite the fact that $42.5 \%$ of the sows culled in the herds evaluated in our investigation were slaughtered up to the 3rd parity, the methodology adopted in the initial stage of the research made verification of the hypothesis linking the disease with sow age impossible. Considering the limitation of the currently available data, it is premature to unequivocally conclude that the genetic development and the management of highly prolific sows in order to obtain the highest possible reproductive performance can be a factor contributing to the increased prevalence of gastric lesions and, consequently, to lower welfare.

The importance of the problem in pigs, in general, has already been recognized by the World Organisation for Animal Health and included in the Terrestrial Animal Health Code. Article 7.13.9 indicates that pigs should be fed with the intention of minimizing the occurrence of gastric ulcers (e.g., by increasing dietary fiber or reducing crude protein); however, these recommendations do not imply direct action in the veterinary legislation of the Member States [30]. Still, it is unknown if those recommendations will be sufficient for sows. Moreover, the examination of stomach is not a part of the routine veterinary-sanitary post-slaughter inspection. Pioneering regulations dealing with this subject are already in force in Denmark. They include intensification of post-mortem inspection of sow stomachs in animals from herds with a statutory contract concluded with an independent veterinary advisor (i.e., either in herds larger than 300 sows, or in those where farmers can administer medicines by themselves, regardless of the farm population). 


\section{Conclusions}

High incidence of gastric ulcers in highly prolific DanBred sows from 4 Polish farms underlines the necessity to continue studies on the influence of different factors affecting gastric integrity at different production phases in order to develop measures to control the disease in sows. Unless new ante mortem diagnostic techniques (other than disadvantageous endoscopial procedure) are developed, abattoir surveys should be used as an objective indicator of animal welfare in intensive farming systems. For this, international consensus should be achieved on the methodology and scoring systems. Due to the character of the disease and its simple and inexpensive monitoring, the assessment of the degree of stomach alterations at slaughter should become a standard tool helping to improve welfare in pig production.

Supplementary Materials: The following are available online at https:/ /www.mdpi.com/article/10 .3390 /agriculture11100927/s1, Table S1. Aggregation of the scores obtained with different evaluation methods for determining gross gastric lesions in sows in earlier studies.

Author Contributions: Conceptualization, P.C.; methodology, J.U.; software, A.W.; validation, P.C., A.W. and T.S.; formal analysis, T.S.; investigation, P.C. and J.U.; resources, P.C.; data curation, A.W.; writing-original draft preparation, P.C. and A.W.; writing-review and editing, T.S.; visualization, P.C. and A.W.; supervision, T.S.; project administration, T.S.; funding acquisition, P.C. All authors have read and agreed to the published version of the manuscript.

Funding: This research received no external funding.

Institutional Review Board Statement: Not applicable.

Informed Consent Statement: Not applicable.

Data Availability Statement: The data presented in this study are available on request.

Acknowledgments: The authors are grateful to Agnieszka Ogrodzińska for her direct technical help.

Conflicts of Interest: The authors declare no conflict of interest.

\section{References}

1. Roels, S.; Ducatelle, R.; Broekaert, D. Keratin pattern in hyperkeratotic and ulcerated gastric pars esophagea in pigs. Res. Vet. Sci. 1997, 62, 165-169. [CrossRef]

2. Penny, R.H.C.; Edwards, M.J.; Mulley, R. Gastric ulcer in the pig: A New South Wales abattoir survey of the incidence of lesions of the pars oesophagea. Br. Vet. J. 1972, 128, 43-49. [CrossRef]

3. Swaby, H.; Gregory, N.G. A note on the frequency of gastric ulcers detected during post-mortem examination at a pig abattoir. Meat Sci. 2012, 90, 269-271. [CrossRef] [PubMed]

4. Friendship, R.M. Gastric ulceration in swine. J. Swine Health Prod. 2004, 12, 34-35.

5. Melnichouk, S. Mortality associated with gastric ulceration in swine. Can. Vet. J. 2002, 43, 223-225.

6. Rutheford, K.M.D.; Thompson, C.S.; Thomson, J.R.; Lawrence, A.B.; Nielsen, O.N.; Busch, E.M.; Haugegaard, S.; Sandøe, P. A study of associations between gastric ulcers and the behaviour of finisher pigs. Livest. Sci. 2018, 212, 45-51. [CrossRef]

7. Cybulski, P.; Larska, M.; Woźniak, A.; Jabłoński, A.; Stadejek, T. The Dietary Risk Factors of Gastric Ulcers in Finishing Pigs from 16 Polish Farms. Agriculture 2021, 11, 719. [CrossRef]

8. De Oliveira, S.J.; Bernardi, R.T.; Vogt, F.I.; Scartezzini, M.; Hepp, D.; Lunge, V.R. Úlceras gástricas em suínos de abate: Cultivo de Arcobacter spp. a partir de estômagos com diferentes graus de lesões. Acta Sci. Vet. 2010, 38, 351-356.

9. Gottardo, F.; Scollo, A.; Contiero, B.; Bottacini, M.; Mazzoni, C.; Edwards, S.A. Prevalence and risk factors for gastric ulceration in pigs slaughtered at 170kg. Animal 2010, 11, 2010-2018. [CrossRef]

10. Ramis, G.; Gomez, S.; Pallares, J.; Munoz, A. Influence of farm size on the prevalence of oesophagogastric lesions in pigs at slaughter in south-east Spain. Vet. Rec. 2004, 155, 210-213. [CrossRef]

11. Anonymous. Prevalentiestudie maagslijmvlieslaesies bij slachtvarkens en slachtzeugen. Royal GD. 2017, 1, 1-7.

12. Christensen, G.; Vestergaard, J. Slagtefund fra udvidet diagnostik (USK) på udsættersøer fra 10 sobesætninger. SEGES $2004,657$.

13. Cybulski, P.; Charęza, T.; Urban, J. Zmiany poubojowe w żołądkach loch. Życie Wet. 2018, 11, 795-796.

14. Nielsen, E.O.; Haugegaard, S.; Jørgensen, L.; Sørensen, G. Mavesundhed hos slagtesvin og slagtesøer. SEGES $2013,975$.

15. Sønderby Bruun, T.; Vinther, J. Ingen sammenhæng mellem søers mavesundhed og foderoptagelse i diegivningsperioden. SEGES 2014, 1013.

16. Vestergaard, K.; Christensen, G.; Brogaard Petersen, L.; Wachmann, H. Afgangsårsager hos søer-Samt obduktionsfund hos aflivede og selvdøde søer. SEGES 2004, 656. 
17. Kopinski, J.S.; McKenzie, R.A. Oesophagogastric ulceration in pigs: A visual morphological scoring guide. Aust. Vet. J. 2007, 85, 356-361. [CrossRef]

18. Berg, J.N. A gastric-ulcer condition in swine. ISU Vet. 1960, 22, 77-78.

19. Vaessen, M.A.H.; Bastiaansen, M.A.C.; Backus, G.B.C. A Comparison between Pig Farming in the European Union and North America; Research Institute for Pig Husbandry: Rosmalen, The Netherlands, 1997; Report P 5.6; ISSN 1385-5883.

20. Anonymous. 2015 Pig Cost of Production in Selected Countries Report; Agriculture and Horticulture Development Board: Kenilworth, UK, 2016; ISBN 978-1-904437-99-4.

21. Anonymous. 2019 Pig Cost of Production in Selected Countries Report; Agriculture and Horticulture Development Board: Kenilworth, UK, 2020; Available online: https://ahdb.org.uk/knowledge-library/2019-pig-cost-of-production-in-selected-countries (accessed on 22 June 2021).

22. Pocock, E.F.; Bayley, H.S.; Roe, C.K.; Slinger, S.J. Dietary factors affecting the development of esophagogastric ulcers in swine. J. Anim. Sci. 1969, 29, 591-597. [CrossRef] [PubMed]

23. Potkins, Z.V.; Lawrence, T.L.; Thomlinson, J.R. Oesophagogastric parakeratosis in the growing pig: Effects of the physical form of barley-based diets and added fibre. Res. Vet. Sci. 1989, 47, 60-67. [CrossRef]

24. Robertson, I.D.; Accioly, J.M.; Moore, K.M.; Driesen, S.J.; Pethick, D.W.; Hampson, D.J. Risk factors for gastric ulcers in Australian pigs at slaughter. Prev. Vet. Med. 2002, 53, 293-303. [CrossRef]

25. Sønderby Bruun, T.; Vinther, J. Mave-USK af udsættersøer afspejler besætningens mavesundhed. SEGES $2013,987$.

26. Engblom, L.; Lundeheim, N.; Strandberg, E.; Schneider, M.P.; Dalin, A.M.; Andersson, K. Factors affecting lenght of production life in Swedish commercial farms. J. Anim Sci. 2008, 86, 432-441. [CrossRef] [PubMed]

27. Hadas, Z.; Schild, M.; Nevrkla, P. Analysis of reasons for culling of sows in production herd. Res. Pig Breed. $2015,2,1-5$.

28. Lucia, T.; Dial, G.G.; Marsh, W.E. Lifetime reproductive performance in female pigs having distinct reasons for removal. Livest. Prod. Sci. 2000, 63, 213-222. [CrossRef]

29. Segura-Correa, J.S.; Ek-Mex, E.; Alzina-Lopez, A.; Segura-Correa, V.M. Frequency of removal reasons of sows in Southeastern Mexico. Trop. Anim. Health Prod. 2011, 43, 1583-1588. [CrossRef] [PubMed]

30. World Organisation for Animal Health. Terrestrial Animal Health Code. 2019. Available online: https://www.oie.int/en/whatwe-do/standards/codes-and-manuals/terrestrial-code-online-access / (accessed on 22 June 2021). 